JAMP: Jurnal Adminitrasi dan Manajemen Pendidikan

Volume 1 Nomor 2 Juni 2018, Hal : 198-205

Tersedia Online di http://journal2.um.ac.id/index.php/jamp/

ISSN 2615-8574 (online)

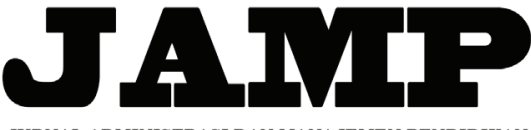

JURNAL ADMINISTRASI DAN MANAJEMEN PENDIDIKAN

\title{
KOMUNIKASI KEPALA SEKOLAH DENGAN WARGA SEKOLAH UNTUK MEWUJUDKAN VISI DAN MISI SEKOLAH
}

\author{
Zusniya Fatmawati \\ Ibrahim Bafadal \\ Ahmad Yusuf Sobri \\ zusniyafatmawati@gmail.com \\ Universitas Negeri Malang, J1. Semarang No. 5 Malang 65145
}

\begin{abstract}
This study aims to describe the principal's communication process, the way the principal establishes communication, the principal obstacle in communication factor in realizing the school vision and mission, and the principal communication support factor in realizing the school's vision and mission. The method used by researchers in this research is qualitative mettode with descriptive research type. And, using various data collection techniques such as in-depth interviews, observation, and documentation. The result of this research are: (a) communication process used by Head of SMPK Kolese Santo Yusup 2 Malang that is direct communication (face to face) and media; (b) how the principal in building communication is by using verbal messages in the form of messages orally and written and non verbal form of action; (c) inhibiting factor of headmaster communication in realizing Vision, SMPK Kollese Santo Yusup 2 Malang Mission, ie human resources; and (d) Principal Communication Supporting Factors to realize Visii and Mission SMPK Kolese Santo Yusup Malang, including: (1) the openness of the principal; (2) a sense of kinship; (3) socialization of vision and also school mission; and (4) Mars Vision, the Mission of Kosayu.
\end{abstract}

Keywords: Principal Communications, School Locals, Vision and Mission School

\begin{abstract}
Abstrak: Penelitian ini bertujuan untuk mendeskripsikan proses komunikasi kepala sekolah, cara kepala sekolah membangun komunikasi, faktor penghambat komunikasi kepala sekolah dalam mewujudkan visi dan misii sekolah, dan faktor pendukung komunikasi kepala sekolah dalam mewujudkan visi dan misi sekolah. Metode yang digunakan peneliti dalam penelitian ini yakni mettode kualitatif dengan jenis penelitian deskriptif. Serta, menggunakan berbagai teknik pengumpulan datta data yaitu wawancara mendalam, observasi, serta dokumentasi. Hasil dari penelitian ini adalah: (a) proses komunikasi yang digunakan Kepala SMPK Kolese Santo Yusup 2 Malang yaitu komunikasi secara langsung (tatap muka) dan bermedia; (b) cara kepala sekolah dalam membangun komunikasi yaitu dengan menggunakan pesan verbal berupa pesan secara lisan dan tulisan serta non verbal berupa tindakan; (c) faktor penghambat komunikasi kepala sekolah dalam mewujudkan Visi, Misi SMPK Kollese Santo Yusup 2 Malang, yaitu sumber daya manusia; dan (d) faktor pendukung komunikasi kepala sekolah untuk mewujudkan Visii dan Misi SMPK Kolese Santo Yusup Malang, diantaranya: (1) keterbukaan kepala sekolah; (2) adanya rasa kekeluargaan; (3) sosialisasi visi dan juga misi sekolah; dan (4) Mars Visi, Misi Kosayu.
\end{abstract}

Kata kunci: Komunikasi Kepala Sekolah, Warga Sekolah, Visi dan Misi Sekolah

Komunikasi ialah cara menyampaikan informassi atau penjelasan dari satu pihak kepada pihak lain secara individu maupun secara kelompok, untuk memperbaiki pendapat maupun perilaku, dengan bertemu langsung dengan orang yang akan diajak untuk berkomunikasi ataupun menggunakan media komunikasi. Hal terpenting bagi manusia ialah komunikasi, karena dengan adanya komunikasi secara 
fasih dapat membantu pelaksanaan tugas dengan baik dan benar. Effendy (2015:4) mengungkapkan, komunikasi dapat berjalan bilamana terdapat kesepadanan arti mengenai sesuatu yang sedang dikomunikasikan oleh orang yang memberi informasi dan penerima informasi. Apabila seseorang memahami mengenai informasi yang dikatakan oleh orang lain kepadanya, maka komunikasi dapat berjalan atau dapat disebut juga hubungan mereka mudah dipahami. Begitu juga sebaliknya jika antara keduanya saling tidak memahami, maka komunikasi tidak akan dapat berjalan. Peranan komunikasi bagi seorang kepala sekolah tidak hanya untuk alat serta sarana berkomunikasi saja melainkan untuk menyampaikan suatu pesan atau informasi. Karena, tidak akan ada satupun organisasi yang dapat berdiri tanpa ada komunikasi serta tidak akan dapat juga menjalankan fungsinya dengan baik tanpa adanya komunikasi. Kepala sekolah merupakan seorang pendidik yang diberi amanah tambahan untuk menjadi seorang pemimpiin sebuah sekolah yang di dalamnya terdapat proses pembelajaran antara sebagai pendidik dan murid sebagai penerima pelajaran. Peran kepala sekolah secara inti adalah sebagai seorang pemimpin. Seorang pemimpin yang mampu berperan sesuai dengan tugas, wewenang, serta bertanggung jjawab untuk mencapai tujuan sekolah (Sobri, 22:2016). Komunikasi kepala sekolah untuk mewujudkan visi dan misi sekolah sangat diperlukan agar visi dan misi sebuah sekolah dapat terwujud. Selain itu, kepala sekolah juga dapat berkolaborasi dengan stakeholder untuk menyusun kebijakan agar dapat mewujukan visi dan misi sekolah.

Visi merupakan tujuan sebuah lembaga pendidikan dan hal apasaja yang harus dilaksanakan oleh lembaga pendidikan dalam usaha untuk mewujudkan visinya tersebut. Sebuah visi wajib menjadi inspirasi serta motivasi bagi seluruh warga sekolah akan ide-ide yang ingin diwujudkan, dan sebuah visi harus dapat menginspirasi gerak kinerja warga sekolahnya, dengan lain kata visi menjadi hal penting bagi suatu lembaga sekolah. Selain visi sebagai alat pendukung menaikkan bobot sekolah, terdapat pula misi. Nawawi (2000: 122) visi ialah pernyataan mengenai tujuan dari sebuah organisasi yang didiekspresikan melalui pelayanan yang ditawarkan dan kebutuhan yang bisa ditanggulangi, nilainilai yang diperole serta harapan dan cita-cita masa depan. Sedangkan misi meripakan penejelasan mengenai sebuah hal yang haruss dikerjakan seuah lembaga pendidikan dalam upaya mewujdukan visi sekolah tersebut, dengan adanya misi sekolah maka tujuan dari visi sekolah dapat lebih tearrah dan terfokuskan. Komunikasi kepala sekolah sangat dibutuhkan supaya mampu mewujudkan visi misi dari sebuah sekolah. Misi adalah kenyataan yang dpat membentuk sebuah organisasi dapat menerbitkan produk serta jasa yang berkualitas untuk memnuhi keperluan, hasrat serta harapan pelanggan (Prasetyo \& Benedicta, 2004:8). Komunikasi juga menjadi modal untuk berinterakaksi antar individu dengan individu yang lainnya. sedangkan, pengertian komunikasi itu sendiri menurut Suranto (2011: 4) yaitu proses pembiaraan pesan maupun informasi yang terdapat arti, dari pengirim informasi kepada penerima informasi denga maksud untuk mencpai tujuan khusus. Kepala sekolah dalam upaya menujudkan visi dan misi dapat bekerjasama dengan warga sekolah lainnya, warga sekolah juga menjadi salah satu faktor penting dalam upaya mewujudkan visi dan misi sekolah. Jadi tanpa adanya keikutsertaan warga sekolah, visi dan misi tidak akan dapat terlaksana.

\section{METODE}

Metode yang digunakan pada penelitian ini adalah kualitatif dengan jenis penelitian deskriptif, yaitu metode penelitian yang hanya memaparkan data dan mengelola data. Metode penelitian kualitatif yaitu metode untuk meneliti dalam kondisi alamiah, peneliti merupakan sebuah instrumen kunci, pada penelitian kualitatif, objek tidak dapat dilihat secara langsung persiall serta dipecah kedalam beberapa variabel. Penelitian kualitatif melihat sebuah objek sebagai sesuatu yang dinamis, hasil kontrruksi pemikiran dan interprestasi terhadap gejala yang diamati, serta utuh karena setiap aspek dari obyek merupakan kesatuan yang tidak bisa dipisahkan (Sugiyono, 2008: 17). Tujuan Penelitian ini yaiitu untuk mendeskripsikan proses komunikasi yang digunakan oleh kepalla sekolah, cara yang digunaka kepala sekolah dalam membangun komunikasi, faktor penghambat kepala sekolah dalam mewujudkan Visi dan Misi SMPK Kolese Santo Yusup 2 Malang, dan faktor pendukung komunikasi kepala sekolah dalam mewujudkan Visi dan Misi SMPK Kolese Santo Yusup 2 Malang. 
Kehadiran peneliti di lapangan sebagai pengamat penuh, peneliti mengamati setiap jalannya kegiatan yang berhubungan dengan komunikasi kepala sekolah dengan warga sekolah untuk mewujudkan visi dan misi sekolah pada SMPK Kolese Santo Yusup 2 Malang. Jadi, peneliti terlibat langsung di lapangan sebagai instrument dan pengumpulan data untuk melakukan kegiatan wawancara mendalam, observasi dan dokumentasi.

Sumber data penelitian ini diperoleh dari informan kunci, informan kunci dari penelitian ini adalah kepala sekloah. Sedangkan informan lainnya yaitu guru, kepala tata usaha, siswa, dan satpam sekolah di SMPK Kolese Santo Yusup 2 Malang. Sumber data informan dapat dilihat pada tabel sebagai berikut.

Tabel Sumber Data Informan

\begin{tabular}{cll}
\hline No. & \multicolumn{1}{c}{ Informan } & \multicolumn{1}{c}{ Jabatan } \\
\hline 1. & Ibu Lusia Ari Kriswati & Kepala Sekolah \\
2. & Ibu Ida Wati & Kepala Staf Tata Usaha \\
3. & Ibu Wahju Kristanti & Guru \\
4. & Ibu Yulia Endah Kaeksi & Guru \\
5. & Bapak Tono Sundari & Satpam Sekolah \\
6. & Mesach & Siswa \\
7. & Nadine & Siswa \\
\hline
\end{tabular}

Peneliti dalam penelitian ini menggunakan teknik pengumpulan data melalui wawancara mendalam, observasi, serta dokumentasi. Teknik dokumentasi digunakan untuk membuktikan faktafakta yang ada dengan bukti tertulis berupa gambar, laporan serta hasil kerja. Sedangkan analisis data dilakukan menggunakan reduksi data, penyajian data dan juga verifikasi data atau penarikan kesimpulan (Ulfatin, 2015), teknik analisis data yang peneliti gunakan dalam penelitian ini adalah reduksi data, peenliti mereduksi data yang didapatkan lalu memilah setiap data sesuai dengan fokusnya masingmasing kemudian setelah melakukan reduksi data peneliti melakukan penyajian data dilakukan dalam bentuk narasi singkat atau teks yang bersifat naratif dan bagan temuan penelitian agar lebih mudah dipahami. Langkah selanjutnya membuat kesimpulan pada setiap masing-masing temuan fokus. Langkah selanjutnya setelah menganalisis data yaitu dilanjutkan dengan pemeriksaan keabsaan data temuan menggunakan tiga teknik triangulasi yaitu (triangulasi sumber, triangulasi metode/teknik, serta triangulasi waktu), pengecekan anggota, perpanjjangan waktu pengamatan, serta kecukupan bahan referensi.

\section{HASIL}

Temuan penelitian pada saat melaksanakan penelitian menunjukkan hasil yaitu: (1) proses komunikasi Kepala SMPK Kolese Santo Yusup 2 Malang, diantaranya: (a) Proses komunikasi tatap muka; dan (b) proses komunikasi menggunakan media yakni dengan media melalui grup whatsapp; (2) cara komunikasi Kepala SMPK Kolese Santo Yusup 2 Malang, diantaranya: (a) pesan verbal berupa lisan dan tertulis; serta (b) pesan non verbal berupa tindakan yaitu dengan cara kepala sekolah memberikan contoh baik seperti mengerjakan pekerjaan tepat waktu, tidak pernah menunda-nunda pekerjaan. Hal tersebut dilakukan kepala sekolah agar dapat diconoth oleh bawahannya; (3) faktor penghambat komunikasi kepala sekolah dalam mewujudkan visi dan misi sekolah, yaitu berasal dari sumber daya manusianya itu sendiri yakni tidak semua guru-guru dan para karyawan sekolah mempunyai sikap yang sesuai dengan yang kepala sekolah harapkan dan tidak semuanya juga mempunyai motivasi yang bagus; dan (4) faktor pendukung komunikasi kepala sekolah dalam mewujudkan visi dan misi sekolah, diantaranya: (a) keterbukaan kepala sekolah; (b) adanya rasa kekeluargaan; (c) sosialisasi visi dan misi SMPK Kolese Santo Yusup dua Malang; dan (d) Mars Visi Misi Kolese Santo Yusup. Temuan penelitian pada saat melaksanakan penelitian di sekolah dapat dilihat pada bagan berikut ini. 


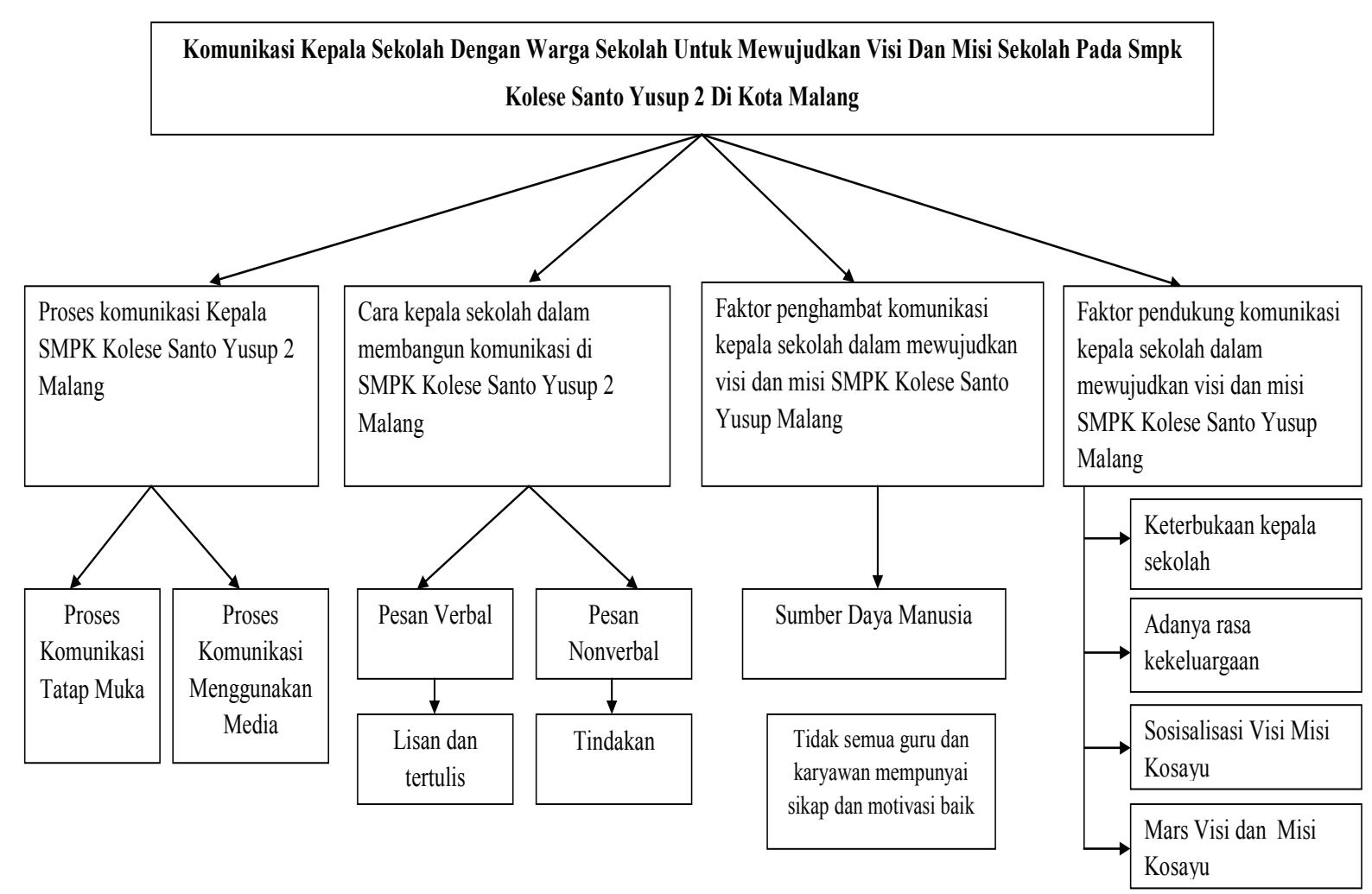

Gambar Bagan Hasil Temuan Penelitian

\section{PEMBAHASAN}

\section{Proses Komunikasi Kepala SMPK Kolese Santo Yusup 2 Malang}

Proses komunikasi yang dilakukan Kepalla SMPK Kolese Santo Yusup 2 Malang dilakukan melalui dua cara yaitu: (a) proses komunikais tatapmuka, proses komunikasi tatap muka tersebut dilakukan oleh kepala sekolah SMPK Kolese Santo Yusup 2 Malang dengan tujuan komunikasi antara kepala sekolah dengan warga sekolah yang lain dapat dapat berjalan lebih baik lagi dan kepala sekolah dapat melihat langsung reaksi lawan bicaranya, serta kepala sekolah bisa memberikan timbal balik (feedback) secara langsung; dan (b) proses komunikasi menggunakan media, seperti halnya mengguankan media whatsapp. Menurut kepala sekolah dengan adaya grup ini sangat membantu proses komunikasi yang ada pada sekolah tersebut. Dengan adanya grup tersebut sangat memudahkan kepala sekolah meskipun sekedar membagi informasi atau membicarakan hal yang penting terkait dengan apapun yang ada pada sekolah tersebut dan bawahan dapat langsung merespon pesan tersebut.

Proses komunikasi yang ditemukan oleh peneliti didukung pendapat Effendy (2015: 6). Terdapat dua prose komunikasi, yaitu: (a) proses komunikasi tatap mukka, dikatakan komunikasi tatap muka karena ketika komunikasi berlangsung, pemberi informasi dan penerima komunikasi dan berhadapan satu sama lain. Pada posisi komunikasi seperti ini penerima informasi dapat secara langsung melihat serta membahas si komunikan. Oleh karena itu, komunikasi tatap muka juga disebut komunikasi langsung (direct communication). Komunikator bisa memahami imbas komunikasi yang dilakukannya seketika itu juga dan respon komunikan dapat langsung diterima oleh komunikator. Oleh karena itu, sering pula pada komunikasi tatahp muka pesan balikan dapat didapat secara langsung. Dilihat dari jumlah pihak penerima pesan yang di hadapi pemberi pesan maka komunikasi tatap muka dibedakan menjadi komunikasi antarpersona dan komunikasi kelompok (Kelompok kecil dan kelompok besar); dan (b) proses komunikasi bermedia, yaitu komunikasi yang menggunakan saluran untuk meneruskan pesan dengan seseorang yang tematnya jauh dengan orang yang memberi informasi maupun dengan penerima pesan yang banyak jumlahnya. Komunikasi menggunakan media bisa juga diseut komunikasi 
tidak langsung, dengan begitu kommunikator tidak langsung mengetahui tanggapan dari komuikan saat berkomunikasi. Maka dari itu, untuk melancarkan komunikais menggunakan media, komunikator dalam perencanaan dan juga mempersiapkan dirinya leih matang lagi agar ia yakin bahwa komunikasi yang dilakukannya itu berhasil. Berdasarkan banyaknya komunikan komunikasi bermedia dikelompokkan menjadi media massa dan media nirmassa.

Cangara (2005:43) menggambarkan proeses komunikasi dinamis, artinya yaitu pesan yang dikirim oleh si pemberi pesan melalui proses utama yang dilakuan oleh sumber pengirim pesan dan proses translasii yang dilakukan oleh penerima pesan. Dapat dilihat saat tahap awal penerima berfungsi sebagai encoder dan penerima sebagai decoder, begitu juga sebaliknya dan juga seterusnya. Cara itu sesuai denga temuan peneliti mengenai proses komunikasi bermedia whatsapp, dimana kepala sekolah mengirimkan pesan kepada bawahannya melalui grup media whatsapp serta bawahan dapat langsung menerima pesan tersebut serta memberikan feedback kepada kepala sekolah.

Baik proses komunikasi langsung tatap muka maupun secara bermedia whatsapp, keduanya sama-sama berkaitan dengan bagaimana komunikasi tersebut berjalan yaitu diawali dengan siapa yang memberikan informasi, pesan apa yang disampaikan, melalui cara apa pesan itu disampaikan, seperti secara langsung bertatap muka maupun menggunakan media, disampaikan kepada siapa, serta pesan berdampak apa bagi si penerima pesan. Temuan penelitian tersebut didukung oleh teori Ardana,dkk (2013:57) proses komunikasi sangat berkaitan dengan bagaimana keberlangsungan komukiikasi tersebut yang diawali: siapa, menyampaikan apa, atau melalui apa, untuk siapa dan berakibat apa.

\section{Cara Kepala Sekolah dalam Membangun Komunikasi di SMPK Kolese Santo Yusup 2 Malang}

Komunikasi Kepala SMPK Kolese Santo Yusup 2 Malang menggunakan cara komunikasi verbal yaitu: (a) secara lisan, cara komunikasi lisan dianggap paling efektif karena penyampaian pesannya dapat secara langsung ke orang yang diajak berkomunikasi; (b) dan tertulis, cara penyampaian pesan selain melalui pesan lisan kepala sekolah juga harus didukung dengan draft pesan tertulis agar dapat memperkuat pesan sehingga dapat lebih dimengerti oleh bawahannya.

Temuan penelitian sinkron dengan pendapat Muhammad (2001:95) dan Cangara (2005:95). Muhammad (2001:95) menyampaikan komunikasi verball adalah karakter yang khas dari manusia. Tidak ada yang bisa menyampaikan macam-mavam arti kata selain manusia, kata-kata yang digunakan untuk penyampaian sebuah pesan dapat dimanipulasi. Kata-kata bisa menjadikan seseorang dapat mengungkapkan ide secara lengkap dan tepat. Kata-kata dapat menjadikan si pengirim mempunyai banyak ide yang disalurkan melalui gelombang udara dan disampaikan kepada orang banyak. Sedangkan, komunikasi verbal menurut Cangara (2005:95) pesan verbal pada pemakaiannya mengunakan bahasa. Bahasa sendiri dapat diartikan seperangkat kata-kata yang disusun secara terstruktur hingga menjadi kalimat yang berarti. Komunikasi non verbal yaitu komunikasi secara tindakan, cara komunikasi secara tindakan tersebut dilakukan agar kepala sekolah dapatt memberikan contoh yang baik kepada warga sekolah. Bertindak sebelum bawahannya melaksanakan, tidak sekedar bicara tetapi harus langsung diwujudkan. Muhammad (2001:95) komunikasi nonverbal merupakan penciptaan atau pertukaran pesan dengan tidak menggunakan kata-kata tetapi menggunakan gerak tubuh, sikap tubuh, tatapan mata, ekspresi, jarak dan sentuhan. Bisa juga dikatakan semua kejadian pada sekeliling situasii komunikasi yang berhubungan dengan berkataan yang diucapkan oleh pemberi informasi.

\section{Faktor Penghambat Komunikasi Kepala Sekolah dalam Mewujudkan Visi dan Misi SMPK Kolese Santo Yusup Malang}

Faktor penghambat komunikasi kepala sekolah SMPK Kolese Santo Yusup 2 Malang agar visi dan misi sekolah dapat terwujud terletak pada sumber daya manusia yang tidak semuanya baik dan tidak semuanya mempunyai motivasi yang bagus. SDM yang kurang memadai bisa menjadikan salah satu faktor penghambat komunikasi agar dapat mewujudkan visi dan misi SMPK Kolese Santo Yusup 2 Malang. Tidak semua guru dan karyawan mempunyai sikap baik dan tidak semuanya mempunyai motivasi yang bagus. Dengan memberikan teguran dan surat peringatan maka akan menjadikan guru 
atau karyawan yang bermasalah tersebut dapat lebih baik lagi. Kepala sekolah melakukan pendekatan kepada karyawan atau guru yang bersangkutan tersebut untuk diajak bicara untuk bersama-sama memecahkan masalah. Kepala sekolah mengatakan bahwa separah apapun masalah itu kuncinya ada pada kepala sekolah, saat kepala sekolah bisa mengendalikan diri maka semuanya akan baik-baik saja.

Temuan penelitian yang telah dipaparkan oleh peneliti sesuai dengan pendapat Fajar (2009:62) yaitu hambatan yang terjadi dari penerima pesan. Karena, faktor penghambat yag terjadi terdapat pada komunikan (karyawan atau guru) yang tidak semuanya baik dalam bekerja seperti sering izin, dan tidak semuanya mempunyai motivasi yang bagus. Dengan begitu kepala sekolah mengajak karyawan atau guru yang bersangkutan berbicara serta dapat memecahkan sebuah masalah tersebut bersama-sama. Dengan begitu pendapat tersebut sesuai faktor penghambat yang ada pada SMPK Kolese Santo Yusup 2 Malang, karena permasalahan penyebab hambatan tersebut bersumber dari komunikan (karyawan atau guru).

\section{Faktor Pendukung Komunikasi Kepala Sekolah dalam Mewujudkan Visi dan Misi SMPK Kolese Santo Yusup Malang}

Faktor pendukung komunikasi kepala sekolah tersebut antara lain yaitu keterbukaan kepala sekolah, adanya rasa kekeluargaan, sosialisasi visi misi sekolah, dan Mars Visi dan Misi SMPK Kolese Santo Yusup Malang. Keterbukaan Kepala SMPK Kolese Santo Yusup 2 Malang dalam berkomunikasi melaksakan pendekekatan dengan mengupayakan dan tidak membatasi dirinya dengan guru, tenaga tata usaha, pegawai sekolah dan juga siswa. Tidak menganggap bahwa status jabatan merupakan suatu penghalang untuk dapat berkomunikasi secara akrab. Artinya kepala sekolah selalu terbuka dengan para bawahannya dengan tidak menjaga jarak, memberikan balasan pesan kepada bawahan kepada bawahan ketika bawahan menyampaikan sesuatu informasi. Temuan penelitian sesuai pendaat Suranto (2011:107-108) menyatakan bahwa faktor komunikasi dilihat dari yang menyampaikan pesan yaitu Kredibilitas, daya tarik, kemampuan intelektual, kesamaan sikap serta perillaku dalam aktiivitas pada tempat kerja sehari-hari, keterpercayaan, kepekaan sosial, kematangan tingkat emosional, memahami kondisi psikolog orang yang diajak bicara, komunikator harus mempunyai sikap yang baik, pekerja keras dan juga tegas, komunikator harus bisa menyesuaikan dimanapun ia berbicara. Temuan penelitian mengenai keterbukaan Kepala SMPK Kolese Santo Yusup 2 Malang dalam berkomunikasi juga sama dengan teori Soekanto (1990) yakni adanya kontak dengan orang lain, dengan kontak atau interaksi dan dengan mengkomunikasikannya, kita dapat saling bertukar pikiran, perasaan, menerima dan memahami perbuatan satu sama lainnya; dan dapat dikatakan berhasil dengan baik jika antara keduanya timbul rasa saling percaya dan mengerti. Dengan sikap keterbukaan kepala sekolah pada bawahannya maka antara keduanya dapat saling bertukar pikiran dan memahami sikap antar kedua belah pihak.

Adanya rasa kekeluargaan antar kepala sekolah dan warga sekoalhnya memiliki rasa saling memiliki dan saling membantu. Dengan adanya rasa kekeluargaan akan tercipta rasa saling menghargai satu sama lain, saling membutuhkan satu sama lainnya. Rasa kekeluargaan menjadi kekuatan bagi Warga SMPK Kolese Santo Yusup 2 Malang, dengan adanya rasa kekeluargaan tersebut akan tercipta kekompakan dalam sekolah tersebut. Temuan penelitian sesuai dengan pendapat Suranto (2011: 107-108) menyatakan bahwa (a) faktor komunikasi dilihat dari pengirim pesan, Kredibilitas, daya tarik, kemampuan intelektual, kesamaan sikap dan perilaku dalam aktivitas tempat kerja sehari-hari, keterpercayaan, kepekaan sosial, kematangan tingkat emosional, komunikator ramah, supel dan tegas, komunikator harus bisa menyesuaikan dimanapun ia berbicara; dan (b) faktor komunikasi dilihat dari komunikan.

Sosialisasi visi dan misi dilakukan kepala sekolah pada saat tahun ajaran baru pada kegiatan OPK (orientasi pendidikan pramuka). Sosialisasi visi dan misi SMPK Kolese Santo Yusup 2 Malang dilakukan kepala sekolah agar sejak awal para siswa sudah terbekali visi dan misi sekolah. Temuan penelitian tersebut sesuai dengan pendapat Ardana, dkk (2013: 64) menyatakan bahwa mendengarkan dengan aktif, banyak orang yang mengangap enteng pekerjaan mendengarkan. Sering mencampur adukkan hal yang berlainan, yakni mendengar dan mendengarkan. Mendengar adalah menangkap vibrasi suara, sedangkan mendengarkan adalah memberi arti kepada apa yang didengar; memberikan umpan balik, 
komunikator harus melihat reaski dari komunikan dengan baik, misalnya dengan ekspresi wajah tertentu bila si komunikan tidak mengajukan pertanyaan. Dengan cara komunikan (penerima informasi) mendengarkan sosialisasi yang diberikan maka penyampaian informasi mengenai visi dan misi sekolah dapat secara jelas diterima oleh komunikan.

Adanya Mars Visi dan Misi SMPK Kolese Santo Yusup 2 Malang mempermudah warga sekolah dalam mengingat atau menghafal visi dan misi sekolah. Mars tersebut dinyanyikan ketika ada acara-acara tertentu yang diadakan oleh SMPK Kolese Santo Yusup 2 Malang dan tidak hanya saat acara tertentu saja, tetapi saat melaksanakan kegiatan upacara bendera dan sebelum pelajaran kesenian mars visi misi tersebut juga di nyanyikan oleh para siswa. Siswa dituntut untuk hafal mars tersebut, bukan hanya para siswa saja yang harus hafal mars visi dan misi Kosayu tetapi para guru juga dituntut menghafal mars tersebut. Temuan penelitian sinkron dengan pendapat Sihabudin (2011:106) baik komunikator maupun audience (penerima informasi) harus menguasai bahasa yng dipakai pada proses komunikasi supaya peesan yang disampaikan dapat dimegerti serta mendapat respon yang sesuai yang diharapkan, artinya kepala sekolah atau guru pada saat menyampaikan misi dan misi kepada siswa harus menggunakan bahasa yang dapat mudah dihafal oleh siswa, misalnya melalui mars visi dan misi sekolah; dan Suranto (2011:107-108) menyatakan faktor komunikasi dilihat dari komunikan, komunikan mudah untuk menerima dan memahami materi yang disampaikan oleh komunikator.

\section{KESIMPULAN DAN SARAN}

\section{Kesimpulan}

Proses komunikasi Kepala SMPK Kolese Santo Yusup 2 Malang dengan warga sekolahh lainnya menggunakan dua proses komunikasi. Proses komunikasi yang pertama yaitu proses komunikasi tatap muka, komunikasi tatap muka tersebut dilakukan oleh Kepala SMPK Kolese Santo Yusup 2 Malang dengan tujuan komunikasi yang terjalin oleh kepala sekolah dengan warga sekolah laiinnya dapat berjalan efektif dan kepala sekolah dapat langsung melihat reaksi dan ekspressi lawan bicaranya, serta kepala sekolah bisa memberikan timbal balik (feedback) secara langsung. Sedangkan, proses komunikasi kedua yaitu proses komunikasi bermedia. Proses komunikasi bermedia yang digunakan Kepala SMPK Kolese Santo Yusup 2 Malang dengan bawahannya yaitu menggunakan media grup whatsapp. Dengan adanya grup tersebut sangat memudahkan kepala sekolah sekedar untuk membagi informasi atau membicarakan hal yang penting terkait dengan apapun yang ada pada sekolah tersebut. Cara komunikasi Kepala SMPK Kolese Santo Yusup 2 Malang dengan warga sekolah lainnya dapat dilakukan dengan menyampaikan pesan verbal yakni lisan dan tulisan serta pesan non verbal secara tindakan. Komunikasi yang digunakan Kepala SMPK Kolese Santo Yusup 2 Malang menggunakan cara komunikasi verbal yaitu secara lisan, komunikasi secara lisan dianggap paling efektif karena dapat langsung menyampaikan pesan tersebut kepada orang yang diajak berkomunikasi dan tertulis, hal ini dilakukan agar dapat lebih dimengerti oleh warga sekolah lainnya. Selain itu kepala sekolah menggunakan cara komunikasi non verbal berupa tindakan, dilakukan kepala sekolah dengan memberikan contoh secara langsung agar dapat ditiru oleh warga sekolah lainnya. Faktor penghambat komunikasi Kepala SMPK Kolese Santo Yusup 2 Malang dalam mewujudkan visi dan misi sekolah terletak pada sumber daya manusiia. Tidak semua guru dan karyawan mempunyai sikap yang sesuai dengan yang kepala sekolah harapkan dan tidak semuanya mempunyai motivasi yang bagus. Dengan memberikan teguran dan surat peringatan maka akan menjadikan guru atau karyawan yang bermasalah tersebut dapat lebih baik lagi. Kepala sekolah melakukan pendekatan kepada karyawan atau guru yang bersangkutan tersebut untuk diajak bicara untuk bersama-sama memecahkan masalah. Kepala sekolah juga mengatakan bahwa separah apapun masalah itu kuncinya ada pada kepala sekolah, saat kepala sekolah bisa mengendalikan diri maka semuanya akan baik-baik saja. Selain itu, dengan adanya grup tersebut kepala sekolah bisa memberikan arahan kepada petugas kebersihan ketika ada barang atau bangunan sekolah yang mendadak perlu dibersihkan atau diperbaiki. Faktor pendukung ialah sesuatu dapat mempengaruhi atau menumbuhkan suatu kegiatan agar dapat lebih baik atau lebih maju dari sebelumnya. Faktor pendukung komunikasi kepala sekolah dalam mewujudkan visi dan misi sekolah tersebut antara lain yaitu: (a) keterbukaan kepala sekolah; 
(b) adanya rasa kekeluargaan; (c) sosialisasi visi dan misi sekolah; dan (d) Mars Visi dan Misi SMPK Kolese Santo Yusup 2 Malang.

\section{Saran}

Berdasarkan hasil penelitian dapat disarankan bagi: (1) Kepala Sekolah SMPK Kolese Santo Yusup 2 Malang, komunikasi Kepala SMPK Kolese Santo Yusup 2 Malang sudah baik. Hal tersebut dibuktikan dengan faktor pendukung komunikasi yang ada, namun diharapkan selalu mempertahankan dan memajukan komunikasi yang telah dijalankan, sehingga dengan kualitas komunikasi bagus maka dapat meujudkanVisi dan Misi SMPK Kolese Santo Yusup 2 Malang; (2) Warga SMPK Kolese Santo Yusup 2 Malang, koomunikasi yang terjadi sudah bagus, diharapkan rasa kekeluargaan antar warga sekolah dipertahankan dan terus dibangun agar komunikasi yang sudah terjain dapat lebih rukun lagi, sehingga hubungan antar warga sekolah bisa terjalin dengan lebih harmonis lagi. Dengan begitu warga sekolah dapat meningkatkan kerjasamanya untuk sama-sama mewujudkan Visi dan Misi SMPK Kolese Santo Yusup 2 Malang; (3) Ketua Jurusan Administrasi Pendidikan Fakultas Ilmu Pendidikan, dari hasil penelitian ini peneliti berharap dapat dijadikan salah satu bahan penelitian mahasiswa terkait komunikasi kepala sekolah untuk mewujudkan visi dan misi sekolah. Serta, agar tetap menjaga kerjasama dengan baik Jurusan Administrasi Pendidikan dengan lembaga sekolah sebagai lokasi penelitian; dan (4) Peneliti lain, diharapkan dengan penelitian ini agar peneliti lain bisa meneruskan penelitian yang sejenis pada berbagai aspek lain dan tempat lain yang belum terungkap terutama tentang komunikasi kepala sekolah denga bidang yang lainnya sesuai dengan Jurusan Administrasi Pendidikan.

\section{DAFTAR RUJUKAN}

Ardana, K. Mujiati, N. \& Sriati, A. 2013. Perilaku Keorganisasian. Yogyakarta: Graha Ilmu.

Cangara, H. 2005. Pengantar Ilmu Komunikasi. Jakarta: PT Raja Grafindo Persada.

Effendy, O. U. 2015. Ilmu Komunikasi Teori dan Praktek. Bandung: PT Remaja Rosdakarya.

Fajar, M. 2009. Ilmu Komunikasi, Teori dan Praktik. Yogyakarta: Graha Ilmu.

Muhammad, A. 2001. Komunikasi Organisasi. Jakarta: PT Bumi Aksara

Nawawi, H. 2000. Manajemen Strategik Ilustrasi di Bidang Pendidikan. Yogyakarta: Gadjah Mada Press.

Sobri, A.Y. 2014. Kepemimpinan Kepala Sekolah Dasar Dalam Menciptakan Sekolah yang Efektif. (Online), (http://ap.fip.um.ac.id/wp-content/uploads/2017/09/output-sekolah-efektif.pdf), diakses tanggal 10 Maret 2018.

Sobri, A. Y. 2014. Kepemimpinan Kepala Sekolah Dalam Meningkatkan Kualitas

Sekolah Dalam Era Masyarakat Ekonomi Asean. (Online), (http://ap.fip.um.ac.id/wp-content/uploads/2017/09/ output-MEA.pdf), diakses tanggal 10 Maret 2018.

Sugiyono. 2011. Metode Penelitian Kualitatif R. \& D. Bandung: Alfabeta.

Suranto, AW. 2011. Komunnikasi Interpersonal. Yogyakarta: Graha Ilmu.

Sihabudin, A. 2011. Komunikasi Antar Budaya. Jakarta: PT. Bumi Aksara

Soekanto, S. 1990. Sosiologi Suatu Pengantar. Jakarta: PT Raja Grafindo.

Ulfatin, N. 2015. Metode Penelitian Kualitatif di Bidang Pendidikan: Teori dan Aplikasinya. Malang: FIP UM 